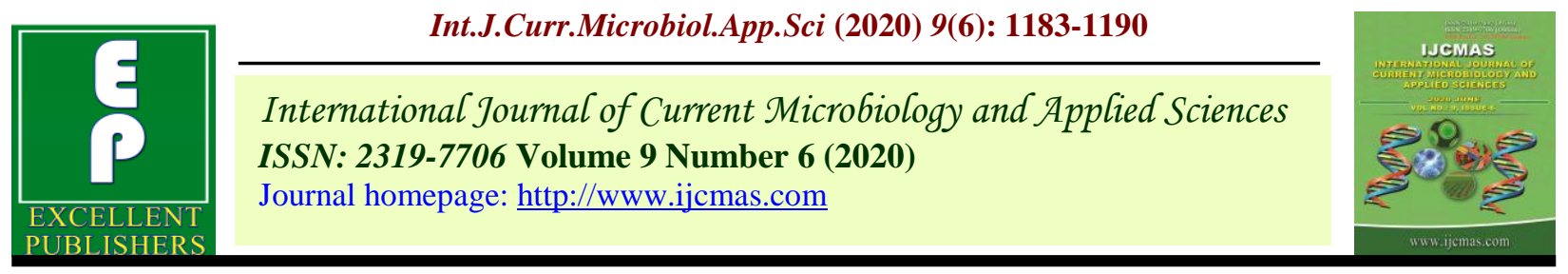

Original Research Article

https://doi.org/10.20546/ijcmas.2020.906.147

\title{
Effect of Evaporative Water Cooled Grinding on Milling Quality of Wheat
}

\author{
P. R. Davara*, V. P. Sangani, P. P. Vora, N. C. Thumar, \\ H. V. Agravat and J. J. Limbasiya
}

Department of Processing and Food Engineering, College of Agricultural Engineering and Technology, Junagadh Agricultural University, Junagadh - 362001

*Corresponding author

\begin{abstract}
A B S T R A C T
Keywords

Wheat, grinding, evaporative water cooling, flour

Article Info

Accepted:

18 May 2020

Available Online:

10 June 2020

Wheat has become one of the most important cereal crops because of its utilization in the flour production. Research was conducted to study the effect of evaporative water cooled grinding on milling quality of wheat. Surface of wheat grain samples were wetted by mixing it with water at four different levels, i.e. $0 \%, 3 \%, 6 \%$ and $9 \% \mathrm{w} / \mathrm{w}$. Wetted grains grinded immediately using domestic hammer mill. Important quality characteristics after milling of wheat samples were studied. Since the evaporating surface water particles taken away the heat generated inside the grinding mill, temperature inside the grinding chamber was decreased. Evaporative water cooled grinding could be completed without any sieve clogging. Grinding time, yield and moisture content of flour were found to be increased in the evaporative water cooled grinded flour. However, the maximum retention of gluten content and minimum temperature rise was observed in the wheat samples mixed with $9 \%$ (w/w) of water. Evaporative water cooled grinding was found to be effective for the better retention of gluten content in the wheat flour.
\end{abstract}

\section{Introduction}

Wheat is the main food cereal of our daily diet. It is consumed mostly in the form of flour. Many milling methods have been developed for grinding of wheat. Stone and roller mills are the two prime methods used for grinding whole grains (Kent and Evers, 1994). Stone mills are being utilized from the ancient times for making whole grain flours. In this method, wheat kernels are grinded between two stones under the combined action of compression, shear, and abrasion (Kihlberg et al., 2004). In the roler mill process, wheat is passed through a series of corrugated and smooth rollers accompanied by sifting between stages.

Hammer mills converts the larger-sized particles into smaller-sized particles applying impact loading (Austin, 2002). Grinding requires a very high power. Out of the total 
energy imparted to the material, only $1 \%$ energy is utilized in loosening the bond between particles, whereas almost $99 \%$ of input energy is being utilized in the heat generation resulting the rise in the temperature of the ground product (Bandara et al., 2014). During grinding of spices, the temperature of a product rises to a level in the range of $42-95{ }^{\circ} \mathrm{C}$ (Pruthi and Misra, 1963; Singh and Goswami, 1997). This can result in considerable damage to starch, protein, and unsaturated fatty acids (Prabhasankar and Rao, 2001). The problem is further complicated by rancidity dangers arising from the cracking of fat molecules which are split into free fatty acids which in turn develop rancidity in the product. The cell damage produced in grinding further has an adverse effect on the protein, amino acids and vitamins (Hanser, 1968). Thus, thermal damage is one of the main limitations of the conventional milling process (Bandara et al., 2014).

The heat generation in the grinding unit can be reduced by decreasing the temperature of the two rubbing surfaces. This can be achieved by circulating cold air or water around the grinder. But this technique is not sufficient enough to significantly reduce the temperature rise of the product (Malkin and Guo, 2007). Energy consumption of grinding biomass depends on initial particle size, moisture content, material properties, feed rate and machine variables etc. (Walde et al., 2002; Mani et al., 2004; Manlu et al., 2003). An increase of grain moisture leads, as a rule, to increased energy requirements of the process, especially when decohesion of grain material is effected with the use of hammer mills (Dziki et al., 2012).

The surface wetting of grains will not affect the products internal moisture content. The surface of grain only remains wetted with water and it will start to evaporate as soon as it gets the energy. During the evaporation, the evaporating particles carry away the thermal energy and the temperature of the system will be decreased (Ketterle and Van Druten, 1996). Evaporative water cooling method has shown promising results in comparison to conventional grinding method for grinding of chilli. The evaporative water cooled ground chilli reported the lower temperature $(36 \pm 1.5$ ${ }^{\circ} \mathrm{C}$ ) as compared to conventionally ground chilli $\left(58 \pm 2.65^{\circ} \mathrm{C}\right)$ (Bandara et al., 2014). No any investigation is carried out to study the effect of evaporative water cooled grinding on the quality aspects of the ground flour. The experiment was conducted with a goal to set the process parameters for evaporative water cooled grinding of wheat which can elevate the flour quality in terms of gluten content along with necessary flour characteristics.

\section{Materials and Methods}

\section{Raw material}

The cultivar Lok-1 is the main variety growing in the Gujarat (India) and processed for the flour production. The wheat grains of selected variety was procured from the Wheat Research Station of Junagadh Agricultural University, Junagadh. The grains were cleaned manually to remove all foreign matters such as dirt, stones, chaff, insect eaten, damaged and broken grains. The cleaned grains were then graded manually by screening with suitable sized sieves to remove the very small sized grains and to obtain uniform sized grains.

\section{Experimental setup}

The low temperature grinding mill as developed by Shelake and Dabhi (2019) was utilized in the experiment. The photograph of grinding mill used in the experiment is shown in the Fig. 1. The commercially available domestic purpose hammer mill was 
purposively selected for grinding of wheat. Grinding chamber of the mill was consisted of four rotating hammers. The running diameter of drum was $19.5 \mathrm{~cm}$. The $3 / 4^{\text {th }}$ inside area of drum periphery was covered with a plate having a grooved surface.

The temperature sensor was fitted inside the grinding chamber to sense the temperature inside the grinding chamber during grinding of wheat. It was further attached with digital temperature indicator fixed outside the grinding mill to record the temperature. The regular sieve size, i.e. 25 mesh as used in the domestic flour mills was utilized for grinding of wheat.

\section{Grinding of wheat}

$1 \mathrm{~kg}$ wheat grain sample from the stock was randomly taken out and used in the experiment. The water was sprinkled over the grain sample at the rate of $0 \%, 3 \%, 6 \%$ and $9 \% \mathrm{w} / \mathrm{w}$. The sample was mixed thoroughly and fed immediately into the hopper of grinding mill. Grinding of the grain was completed before the surface water penetrated into the grain. Another $1 \mathrm{~kg}$ of wheat grain sample was ground without mixing of water using the same hammer mill and sieved to compare it with wheat flour sample obtained with evaporative water cooled grinding.

\section{Flour characteristics}

\section{Moisture content}

The initial moisture content of wheat grain sample was determined by hot air-oven method. 2 to $3 \mathrm{~g}$ of ground samples were weighed and transferred into 2 to 3 petri dishes, which were covered with lids immediately. The dishes were then uncovered and placed in a hot air oven at a temperature of $130 \pm 1^{\circ} \mathrm{C}$ for $1 \mathrm{~h}$ (Sahay and Singh, 2001). Same procedure was followed in case of wheat flour. Moisture content of sample was then determined by using the following formula.

Moisture content $(\%$, w.b. $)=\frac{\text { Initial wt. of sample }-0 \text { ven dried wt. of sample }}{\text { Initial wt. of sample }} \times 100$

\section{Flour temperature}

The flour temperature was recorded as soon as it came out from the grinding chamber. It was measured by digital thermometer by inserting the bulb/sensor of the thermometer inside flour at four various locations without disturbing the flour. It was then averaged.

\section{Flour yield}

The percentage flour yield was calculated by taking the ratio of weight of flour to the weight of wheat.

Flour yield, $\%=\frac{\text { Weight of flour }(\mathrm{g})}{\text { Weight of wheat }(\mathrm{g})} \times 100$

\section{Gluten content}

The gluten content of wheat flour was determined using the gluten analyzer. Sample was prepared by taking $10 \mathrm{~g}$ of wheat flour in plastic egg shaped sample cup. $5.5 \mathrm{ml}$ of salted water solution was added and sample cup was shacked vigorously to mix the flour with water. The sample was then washed using automatic washer. It was then centrifuged to remove the washing solution from the dough. The mass of the gluten was then measured to determine the gluten content using following formula.

Wet gluten $(\%)=$ Gluten mass X 10

\section{Ash content of flour}

The ash content was determined according to the method referred by AOAC (2005). $5 \mathrm{~g}$ of 
wheat flour sample was taken into a silica dish. The dish with content was ignited on a bunsel burner. The material was then ashed at $425{ }^{\circ} \mathrm{C}$ for $4 \mathrm{~h}$ in a muffle furnace. The dish was cooled and weighed. The total ash content was calculated by difference in weights and was expressed as percent ash.

\section{Statistical analysis}

Statistical analysis was done to study the effect of selected process parameter like mixed water quantity on dependent parameters by Completely Randomized Design (simple CRD) (Panse and Sukhatme, 1985). The results of evaporative cooled grinded wheat flour were compared with the flour grinded through conventional method, i.e. without addition of water. All the treatments were compared at 5\% level of significance using the Critical Difference test. The Analysis of Variance (ANOVA), Standard Error of mean (SEm), Critical Difference (CD) and Coefficient of Variance (CV) for dependent parameter were tabulated and the level of significance was reported.

\section{Results and Discussion}

\section{Flour characteristics}

The various flour characteristics like temperature, yield, moisture content, gluten content and ash content of wheat flour at different mixed water levels are given in Table 1.

\section{Flour temperature}

Table 1 revealed that the average wheat flour temperature was significantly lowest for the treatment $\mathrm{W}_{3}$ (9\% mixed water quantity) whereas significantly highest for the treatment $\mathrm{W}_{0}$ (without mixing of water). From the Fig. 2 , it could be seen that wheat flour temperature was ranged from $56.1{ }^{\circ} \mathrm{C}$ to 71.6
${ }^{\circ} \mathrm{C}$. The maximum wheat flour temperature $\left(71.6{ }^{\circ} \mathrm{C}\right)$ was found for control treatment, i.e. without mixing of water whereas minimum $\left(56.1{ }^{\circ} \mathrm{C}\right)$ was found for treatment $\mathrm{W}_{3}$, i.e. $9 \%$ mixed water. The flour temperature in the surface wetted grain was ranged from $56.1{ }^{\circ} \mathrm{C}$ to $71.4{ }^{\circ} \mathrm{C}$ which showed that the flour temperature was decreased upon surface wetting of grain surface before milling.

For the initial wetting levels i.e. control and $3 \%$ mixed water, there was a negligible decrease $\left(0.02{ }^{\circ} \mathrm{C}\right)$ in flour temperature. However, it was significantly reduced as the surface wetting was improved from $3 \%$ to $9 \%$. Overall, the surface water mixing up to its highest selected level (9\%) could decrease the flour temperature by maximum of $15.5^{\circ} \mathrm{C}$ in comparison to control treatment. The maximum of $11^{\circ} \mathrm{C}$ decrease in the grinding temperature during grinding of surface wetted wheat grain was observed by Davara et al., (2018). Reduction in grinding temperature of evaporative water cooled grinding was also reported by Bandra et al., (2015).

\section{Flour moisture content}

The minimum wheat flour moisture content $(6.11 \% \mathrm{wb})$ was found for control treatment, i.e. without mixing of water whereas maximum of it $(10.54 \% \mathrm{wb})$ was found for treatment $\mathrm{W}_{3}$, i.e. $9 \%$ mixed water quantity (Fig, 2). The flour moisture content in control treatment was $6.11 \%$ which was increased in the range of $7.62 \%$ to $10.54 \%$ in surface wetted wheat grains. Gradual increase in the flour moisture content was noted with the increase in the percentage of water added. The flour moisture content was increased by maximum of $4.43 \%$ in case of wheat added with $9 \%$ water in comparison of control treatment. The increase in wheat flour moisture content for surface wetted wheat samples can be attributed to the absorption of moisture by flour particles. 
Table.1 Flour characteristics of wheat for different treatments

\begin{tabular}{|c|c|c|c|c|c|}
\hline Treatment & $\begin{array}{l}\text { Flour temp. } \\
\qquad\left({ }^{\circ} \mathrm{C}\right)\end{array}$ & $\begin{array}{c}\text { Flour yield } \\
\text { (g) }\end{array}$ & $\begin{array}{l}\text { Moisture } \\
\text { content } \\
(\% \text { wb) }\end{array}$ & $\begin{array}{c}\text { Ash content } \\
(\%)\end{array}$ & $\begin{array}{c}\text { Gluten } \\
\text { content }(\%)\end{array}$ \\
\hline $\mathbf{W}_{\mathbf{0}}$ & 71.6 & 755 & 6.11 & 1.64 & 11.37 \\
\hline $\mathbf{W}_{1}$ & 71.4 & 804 & 7.62 & 1.57 & 13.09 \\
\hline $\mathbf{W}_{2}$ & 62.7 & 830 & 8.59 & 1.55 & 12.82 \\
\hline $\mathbf{W}_{\mathbf{3}}$ & 56.1 & 870 & 10.54 & 1.54 & 12.81 \\
\hline S.Em. \pm & 0.130 & 3.746 & 0.060 & 0.007 & 0.020 \\
\hline C.D. at $5 \%$ & 0.391 & 11.232 & 0.181 & 0.021 & 0.060 \\
\hline C.V. \% & 0.445 & 1.028 & 1.640 & 0.996 & 0.357 \\
\hline
\end{tabular}

Treatments : $\quad \mathrm{W}_{0}$ : Control (Without water mixing), $\mathrm{W}_{1}: 3 \%$ water mixing, $\mathrm{W}_{2}: 6 \%$ water mixing, $\mathrm{W}_{3}: 9 \%$ water mixing,

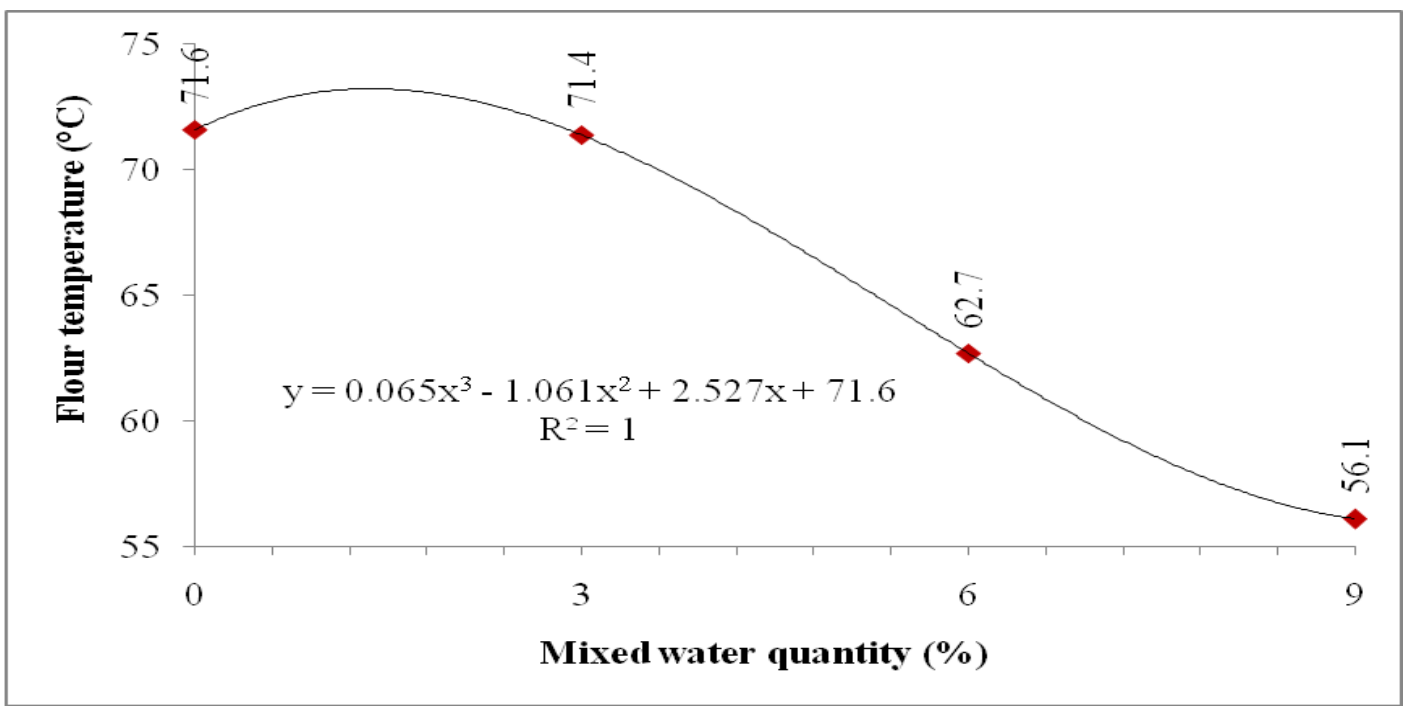

Fig.1 Variation in wheat flour temperature during evaporative water cooled grinding

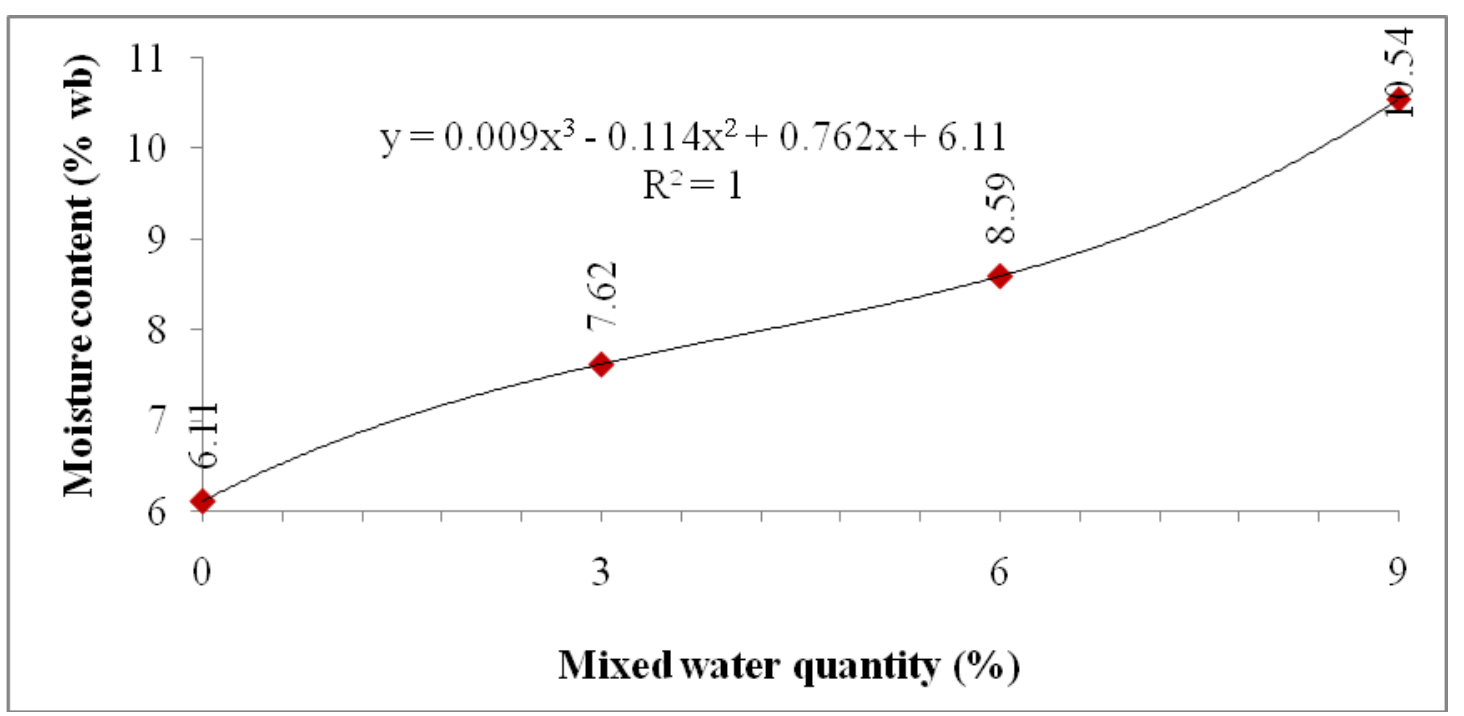


Fig.2 Variation in the flour moisture content under evaporative water cooled grinding

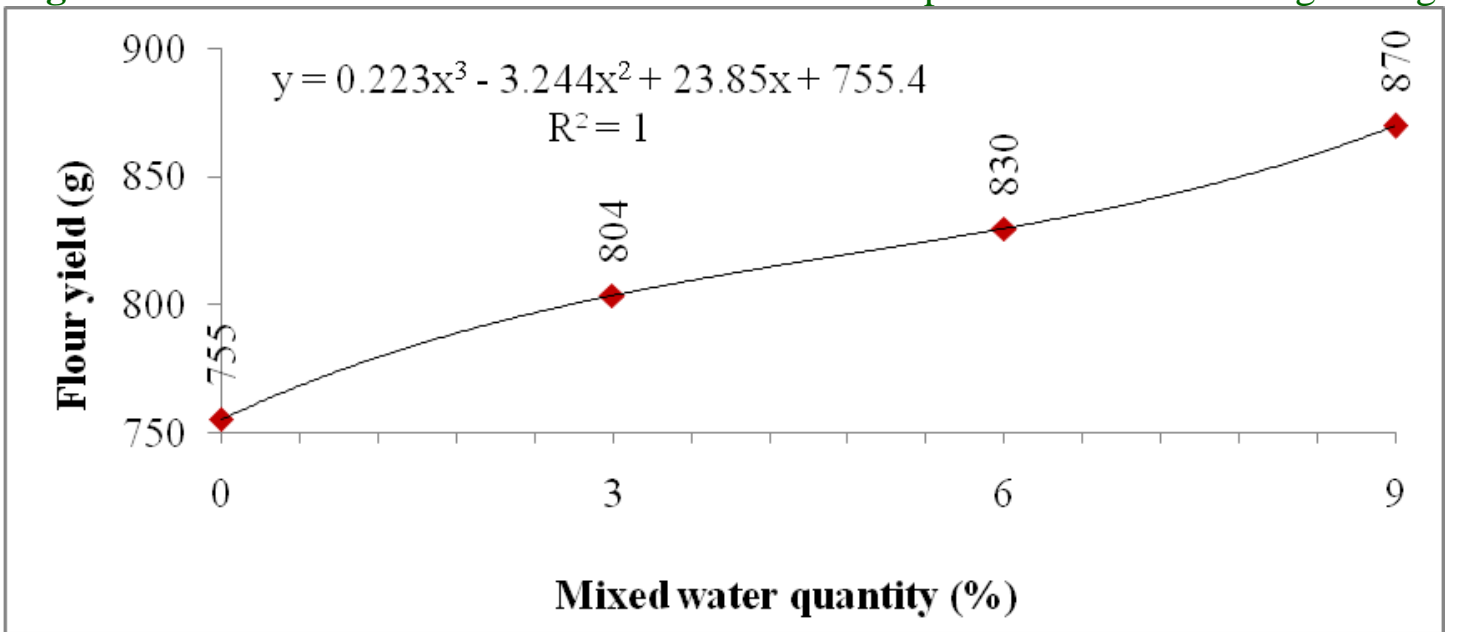

Fig.3 Variation in the wheat flour yield during evaporative water cooled grinding

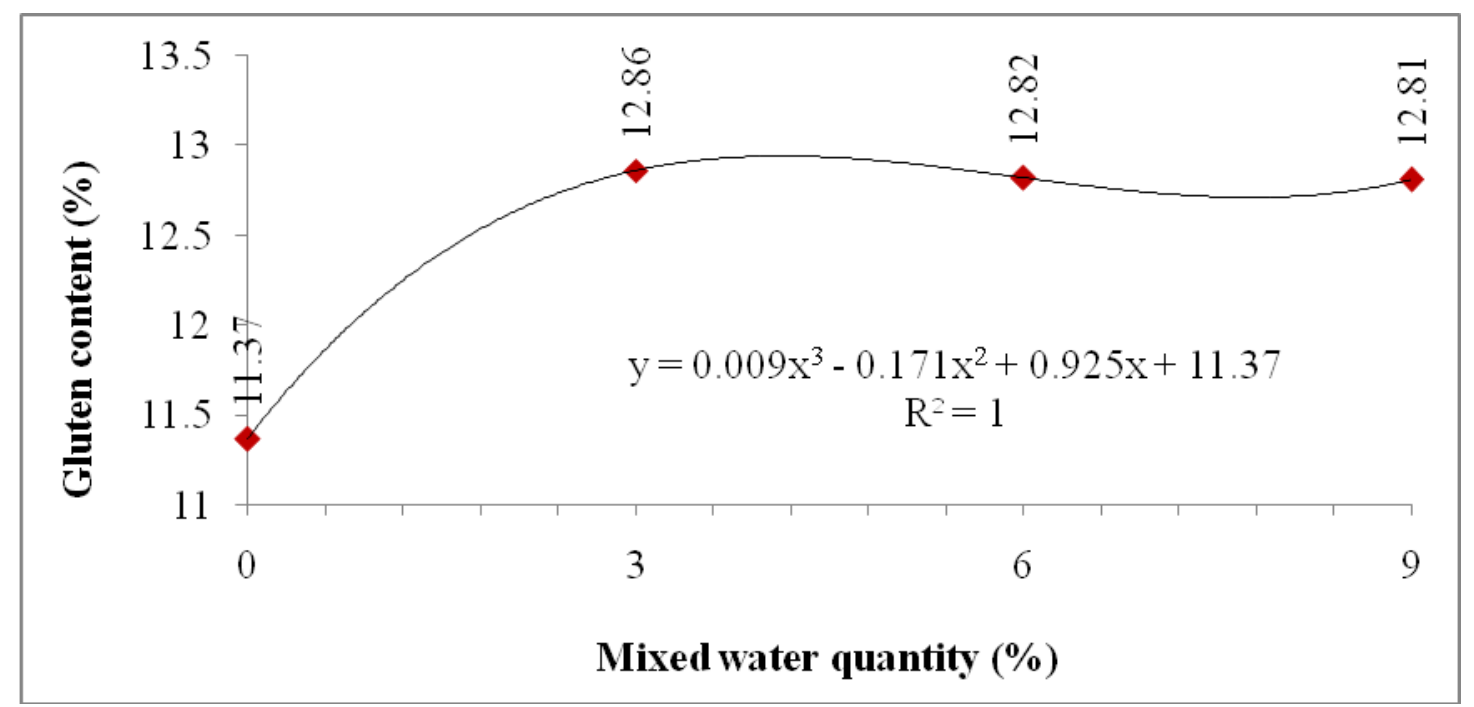

Fig.4 Effect of evaporative water cooled grinding on gluten content of wheat flour

During grinding, the whole wheat grain was converted into flour which is highly hygroscopic in nature. Hence, the rate of absorption of moisture by flour particles was increased and resulted in increase of flour moisture content. Hence, the increase in the moisture content of flour is due to the absorption of water.

\section{Flour yield}

Significantly lowest flour yield was observed for the treatment $\mathrm{W}_{0}$ (without mixing of water) (Table 1). Wheat grain added with $9 \%$ surface water $\left(\mathrm{W}_{3}\right)$, reported the maximum wheat flour yield $(870 \mathrm{~g})$ whereas control treatment reported the minimum flour yield (755.4 g) (Fig. 3). Flour yield for the surface wetted wheat grains was ranged from $804 \mathrm{~g}$ to $870 \mathrm{~g}$ as against the $755 \mathrm{~g}$ in control treatment. This indicated the maximum rise of $115 \mathrm{~g}$ flour yield during evaporative water cooled grinding of wheat added with $9 \%$ surface moisture. Absorption of the moisture by flour particles increased their adhesiveness, which reduces the loss of flour particles in the air and flour collection efficiency was increased. Hence, the increase 
in the flour yield is due to increase in the moisture content of flour.

\section{Gluten content of wheat flour}

The data of gluten content as shown in Table 1 , revealed that the retention of gluten content was lowest in the control treatment, whereas highest in the treatment $\mathrm{W}_{1}(3 \%$ mixed water quantity). However, negligible difference in the gluten content was observed between different treatments, i.e. $\mathrm{W}_{1}, \mathrm{~W}_{2}$ and $\mathrm{W}_{3}$. The graphical presentation of variation in the gluten content of different treatments is given in Fig. 4. From the figure, it could be observed that the gluten content of wheat flour was ranged from $11.37 \%$ to $12.86 \%$. The results showed that the gluten content in control treatment was $11.37 \%$ while it it was comparatively higher and in the range of $12.81 \%$ to $12.86 \%$ in the flour prepared under evaporative cooled conditions. For the smaller quantity of mixing water, i.e. $3 \%$, considerable increase $(12.86 \%)$ in gluten content was obtained. But, it was found to be decreased slightly as the quantity of mixed water was increased from $3 \%$ to $6 \%$ and from $6 \%$ to $9 \%$. Evaporative water cooled grinding of grains by mixing of $3 \%$ water increased the gluten content of flour by maximum of $1.44 \%$ in comparison to control treatment.

The increase in gluten content for surface wetted wheat samples can be attributed to the process of evaporative cooling taken place during the grinding. As the grinding time proceeded, the temperature inside the grinding chamber was increased in all the treatments. However, the rate of increase in the temperature was lower in the surface wetted grains due to loss of heat through evaporative cooling. Evaporative cooling controlled the elevation of temperature inside the grinding chamber which ultimately prevented the loss of gluten content and preserved it in the surface wetted samples. Better retention of colour in the chili powder under evaporative water cooled grinding was also reported by Bandara et al., (2015).

Evaporative water cooling method has shown promising results for the preparation of wheat flour with better quality attributes. Effect of evaporative water cooled grinding on flour moisture content, flour temperature, flour yield and gluten content was studied. The wheat flour grinded through EWC system gave the comparatively higher moisture content and flour yield and lower flour temperature as against the normal grinding. Maximum decrease of $11^{\circ} \mathrm{C}$ flour temperature could be obtained when the wheat was grinded through evaporative cooled grinding system. EWC grinding has also benefited by retaining the more gluten content in the flour as compared to normal grinding process. Therefore, evaporative water cooled grinding of wheat could be suggested as the effective method for size reduction process of cereal grains.

\section{References}

Austin, L. (2002). A treatment of impact breakage particles. Powder Technology, 126(1) : 85-90.

Bandara, D. M. S. P., Amarathunga, K. S. P., Thilakaratne, B. M. K. S., Dissanayake, T. M. R., Dharmasena, D. A. N. and Fernando, A. J. (2014). Feasibility study of evaporative water cooled (EWC) grinding method for chilli (Capsicum annum L.). Tropical Agricultural Research, 26(1) : 189-194.

Bandara, D. M. S. P., Amarathunga, K. S. P., Thilakaratne, B. M. K. S., Dissanayake, T. M. R., Dharmasena, D. A. N. and Fernando, A. J. (2015). Use of evaporative water cooling (EWC) in grinding chili. Engineer, 48(3) : 13-17.

Davara, P. R., Thumar, N. C., Limbasiya, J. J., Agravat, H. V. and Sangani, V. P. (2018). Effect of surface wetting on grinding characteristics of wheat. 
Advances in Food Science and Engineering, 2(1):48-53.

Dziki, D., Pietrzak, G. C., Biernacka, B., Jończyk, K., Różyło, R. and Gładyszewska, B. (2012). The grinding energy as an indicator of wheat milling value, Teka. Commission of Motorization and Energetics in Agriculture, 12(1) : 29-33.

Hanser, W. F. (1968). Reduction of cereal grains to flour. Unites States Patent No. US3399838A. Accessed at https://www.google.ch/patents/US3399 838.

Kent, N. L. and Evers, A. D. (1994). Technology of Cereals. Elsevier : Tarrytown, NY.

Ketterle, W. and Van Druten, N. J. (1996). Evaporative cooling of trapped atoms. Advances in Atomic, Molecular and Optical Physics, 37 : 181-236. DOI: 10.1016/S1049-250X(08)60101-9.

Kihlberg, I., Johansson, L., Kohler, A. and Risvik, E. (2004). Sensory qualities of whole wheat pan bread - influence of farming system, milling, and baking technique. Journal of Cereal Science, $39: 67-84$.

Malkin, S. and Guo, C. (2007).Thermal Analysis of Grinding. Annals of the CIRP. Connecticut, USA. Science Direct, 56 (2) : 760-782.

Mani, S., Tabil, L. G. and Sokhansanj, S. (2004). Grinding performance and physical properties of wheat and barley straws, corn stover and switch grass.
Biomass and Bioenergy, 27 : 339-352.

Manlu, Y. U., Womac, A. R. and Pordesimo, L. O. (2003). Review of biomass size reduction technology. ASAE Paper No. 036077. St. Joseph, Mich.: ASAE.

Panse, V. G. and Sukhatme, P.V. (1985). Statistical Methods for Agricultural Workers, Fourth Editions. ICAR, New Delhi.

Prabhasankar, P. and Rao, P. H. (2001). Effect of different milling methods on chemical composition of whole wheat flour. European Journal of Food Research and Technology, 213 : 465469.

Pruthi, J. S. and Misra, B. D. (1963). Physical, chemical and microbiological changes in curry powders during drying, milling and mixing operation. Spices Bull. 3: 9-13.

Sahay, K. M. and Singh, K. K. (2001). Unit Operations of Agricultural Processing ( $2^{\text {nd }}$ Revised Edition), Vikas Publishing House Pvt. Ltd., Noida, India.

Shelake, P. S. and Dabhi, M. N. (2019). Development of cooling assisted grinding system mechanism for spices. Journal of Food Process Engineering, 42(8): $1-6$, https://doi.org/10.1111/jfpe.13288.

Walde, S. G., Balaswamy, K., Velu, V. and Rao, D. G. (2002). Microwave drying and grinding characteristics of wheat (Triticum aestivum), Journal of Food Engineering, 55 : 271-276.

\section{How to cite this article:}

Davara. P. R. V. P. Sangani, P. P. Vora, N. C. Thumar, H. V. Agravat and Limbasiya. J. J. 2020. Effect of Evaporative Water Cooled Grinding on Milling Quality of Wheat. Int.J.Curr.Microbiol.App.Sci. 9(06): 1183-1190. doi: https://doi.org/10.20546/ijcmas.2020.906.147 